\title{
ARBUSCULAR MYCORRHIZAS IN THE ROOTS OF AFZELIA AFRICANA, ENTADA AFRICANA, AND PTEROCARPUS ERINACEUS
}

\author{
DJOTAN, A. K. G. ${ }^{1,2,4^{*}}$ - MATSUSHITA, N. ${ }^{1}$ - VAARIO, L. M. ${ }^{1,3}-$ YOROU, N. S. ${ }^{4}$ - FUKUDA, K. ${ }^{1}$ \\ ${ }^{1}$ University of Tokyo, Graduate School of Agricultural and Life Sciences (Laboratory of Forest \\ Botany), 1-1-1, Yayoi, Bunkyo-ku, Tokyo 113-8657, Japan \\ (phone: +81-807-805-0737) \\ ${ }^{2}$ University of Abomey-Calavi, Graduate School of Environment Planning (Laboratory of \\ Forest Sciences), BP 1493 Abomey-Calavi, Benin \\ (phone: +81-907-284-0398) \\ ${ }^{3}$ University of Helsinki, Department of Forest Sciences, PO Box 27, FI-00014 Helsinki, Finland \\ (phone: +358-505-706-228) \\ ${ }^{4}$ University of Parakou, Research Unit "Tropical Mycology and Plants-Soil Fungi \\ Interactions”, BP 123 Parakou, Benin \\ (phone: +229-9424-3866) \\ *Corresponding author \\ e-mail: geoffroydjotan@yahoo.fr; phone: +81-807-805-0737 \\ (Received 25 $5^{\text {th }}$ May 2020; accepted 20 $0^{\text {th }}$ Aug 2020)
}

\begin{abstract}
Afzelia africana, Entada africana, and Pterocarpus erinaceus are economically important tropical tree species in Africa. In this study, we performed morphological and molecular analyses to examine the mycorrhizal status of these species in their natural habitat in Benin, West Africa. Fine roots were examined using trypan blue staining. Putative arbuscular mycorrhizal fungi (AMF) were identified by extracting root DNA and sequencing the large subunit region of ribosomal DNA. Operational taxonomic units (OTUs) were positioned on a consensus phylogenetic tree produced using maximum likelihood and neighbor-joining models. Morphological analyses revealed vesicles, arbuscules, and inter- and intracellular hyphae in roots of all three tree species. Molecular analyses revealed 39 AMF OTUs, among which 18 were from roots of E. africana, 15 from P. erinaceus, and 9 from A. africana. These OTUs belonged to Glomus, Nanoglomus, Rhizoglomus, Sclerocystis, Septoglomus, and Scutellospora; two unidentified species belonged to the family Glomeraceae. This is the first study to report AMF in roots of A. africana, E. africana, and $P$. erinaceus in Benin, and opens new avenues for future studies.
\end{abstract}

Keywords: $A M F$, Benin, LSU, mycorrhiza, plant improvement, tropical tree species, Wari-Maro forest, West Africa

\section{Introduction}

Mycorrhizas are essential symbiotic associations that allow nutrient transfer between fungi and the roots of living plants (Brundrett, 2004). Mycorrhizal symbioses provide multiple benefits for the functioning of natural ecosystems (Smith and Read, 2008), including nutrition enhancement (Clark and Zeto, 2000; Bücking and Kafle, 2015; Bunn et al., 2019), drought stress alleviation (Sharma et al., 2015; Dar et al., 2018), soil pathogen resistance (Talavera et al., 2001; Makoi and Ndakidemi, 2009), and growth of the host plant, as well as soil structure stabilization (Aggarwal et al., 2011). In tropical forests, most Dipterocarpaceous and Myrtaceaous trees form ectomycorrhizal symbioses, and many other angiosperm species form arbuscular mycorrhizas (Wang and Qiu, 2006; 
Smith and Read, 2008; Brundrett, 2009). However, information on the mycorrhizal status of valuable tree species is limited for West African tropical forests. Ectomycorrhiza in Afzelia africana Sm. have previously been reported (Redhead, 1968; Ba and Thoen, 1990; Yorou et al., 2008); however, the presence of arbuscular mycorrhizal fungi (AMF) in the roots of this species has not been confirmed, and there have been no reports of the mycorrhizal status of Entada africana Guill. \& Perr. or Pterocarpus erinaceus Poir.

Afzelia africana is a vulnerable species (African Regional Workshop, 1998), also known as African mahogany. It is a deciduous tree belonging to the Detarioideae subfamily (Fabaceae), that is valued for the quality of its hard, reddish wood (Bayer and Waters-Bayer, 1999; Sinsin et al., 2004) and for the high nutritional value of its leaves as cattle feed (Sinsin, 1993). Seeds of this species germinate easily; however, the low recruitment rate of seedlings hinders natural regeneration (Padonou et al., 2013), particularly in its fire-prone natural habitats (Bationo et al., 2001). As a consequence of human pressures (Houehanou et al., 2019) and seedling recruitment issues, the population of $A$. africana is decreasing; only adult trees of this species are commonly observed in its natural habitats (Padonou et al., 2013). However, despite the frequent pruning of these adult trees, they continue to persist.

Entada africana, a species of least concern (Botanic Gardens Conservation International, International Union for Conservation of Nature SSC Global Tree Specialist Group, 2019) known as fake locust bean, is a deciduous tree species belonging to the subfamily Caesalpinioideae (Fabaceae); all of its organs are used as traditional medicines (Tibiri et al., 2007, 2010). The roots, stem bark, and leaves of this species contain many phytochemical classes of compounds including polyphenols, terpenes, and alkaloids (Sanogo et al., 1998; Ahua et al., 2007; Tibiri et al., 2007, 2010; Mbatchou et al., 2011), which can be further improved by mycorrhizal associations (Sbrana et al., 2014).

Pterocarpus erinaceus, known as African rosewood, is a deciduous tree species belonging to the subfamily Faboideae (Fabaceae), that has high wood quality (Traore et al., 2010; Segla et al., 2017). This species is selectively logged in natural forests (Adjonou et al., 2010; Rabiou et al., 2015); the processed wood is exported to China, India, and other countries (Segla et al., 2017). The species is also valued as animal feed (Olafadehan, 2013). It is now an endangered species (Barstow, 2018) due to its low growth rate (Dumenu and Bandoh, 2016) and overexploitation (Dumenu, 2019).

Our long-term research goals are to test the potential of mycorrhizas for improving seedling recruitment in A. africana, the growth rate of $P$. erinaceus, and the quality and quantity of phytochemical production in E. africana. As a first step, in this study, we investigated the mycorrhizal status of these three tree species through anatomical observation of their roots and molecular detection of putative mycorrhizal fungi.

\section{Materials and Methods}

\section{Study site and sampling}

Sampling was conducted in the Wari-Maro Forest Reserve in Benin, West Africa, in July 2019. The reserve includes dense forests, woodlands, and savannahs in the SudanoGuinean phytodistrict defined by Aubréville (1970) and White (1983) in the tropical climate zone $\left(8.80-9.20^{\circ} \mathrm{N}, 1.95-2.45^{\circ} \mathrm{E}\right)$ overlapping the Tchaourou and Bassila districts (Fig. 1) (Salako et al., 2014; DIVA-GIS, 2018; Djotan et al., 2018). Samples were collected and transported to Japan under official regulations. 

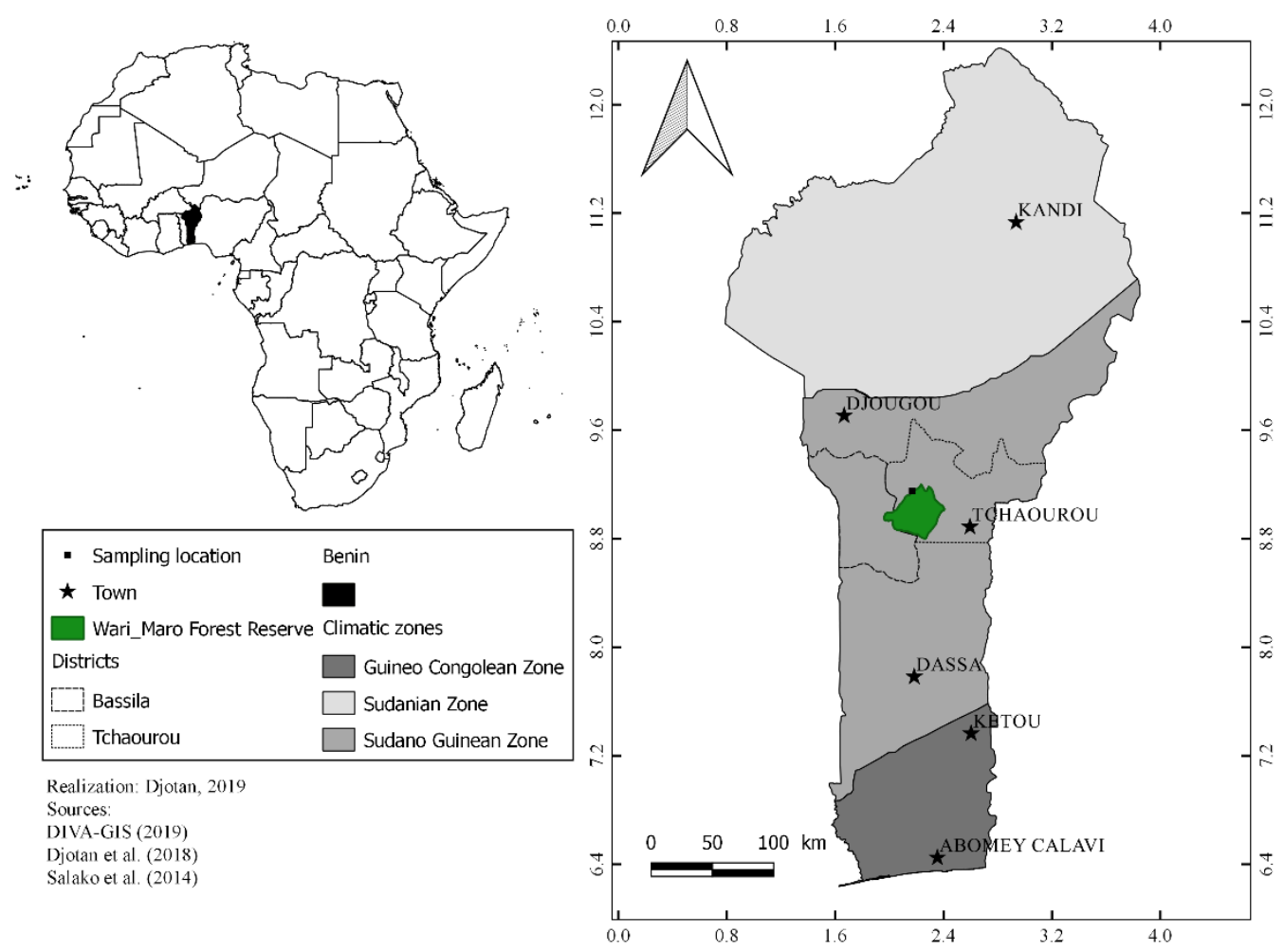

Figure 1. Sampling locations. Green polygon indicates the Wari-Maro Forest Reserve, which overlaps two districts of central Benin, West Africa. Samples were collected around the black point within the polygon

Five individual trees of each species were randomly sampled in the forest reserve. We collected $50 \mathrm{~g}$ of fine roots, including first- and second-order lateral roots, from each tree. We ensured that the collected roots belonged to the targeted tree by tracing the excavated roots to the base of the tree. Each root system sample was kept fresh within its rhizosphere and transported to the laboratory in a plastic test tube. Roots were washed three times with running tap water to remove soil particles attached to the root surface, and then preserved in $60 \%$ ethanol until further use.

\section{Staining and anatomical observation}

The root segments were cleaned and stained (Phillips and Hayman, 1970), and stained roots were preserved in lacto-glycerol until observation (Brundrett et al., 1984). For each tree, 10 root segments (length, $1 \mathrm{~cm}$ ) were randomly cut, mounted with lacto-glycerol, and observed under a microscope (BX50, Olympus, Tokyo, Japan) fitted with a camera (DP71, Olympus) featuring standard bright-field optics. Based on the resulting microscopy images, we calculated the colonization frequencies of arbuscular mycorrhiza for each species as the number of tree samples of the species in which mycorrhizal features were observed $(n=5)$. Colonization intensity was calculated as the relative length of slide-mounted roots containing mycorrhizal features to the total length of observed roots (Giovannetti and Mosse, 1980; Fujimaki et al., 2001). We confirmed AMF colonization by observation of arbuscules, vesicles, intracellular hyphae, or intercellular hyphae with branches inside cells. 


\section{DNA extraction, polymerase chain reaction (PCR) amplification, and sequencing}

To identify the root fungal community composition, DNA was extracted from root segments (three randomly selected $1 \mathrm{~cm}$ root segments) of each sampled tree using the DNeasy Plant Mini Kit (Qiagen, Hilden, Germany) according to the manufacturer's instructions.

We performed 10-fold dilution of the extracted root DNA samples for use as a DNA template for PCR. We used the nested PCR method to amplify the large subunit (LSU) region of the fungal ribosomal DNA (rDNA) (Gollotte et al., 2004). We used the eukaryote-specific primer LR1 (5'-GCATATCAATAAGCGGAGGA-3') (Van Tuinen et al., 1998), and the fungus-specific primer FLR2 (5'-GTCGTTTAAAGCCATTACGTC-3') (Trouvelot et al., 1999) in the first round of PCR. The resulting PCR products were diluted 100-fold and used as a template for second-round PCR with the general AMF nested primers FLR3 (5'-TTGAAAGGGAAACGATTGAAGT-3') and FLR4 (5'-TACGTCAACATCCTTAACGAA-3') (Gollotte et al., 2004). Both rounds of PCR were performed in a $6 \mu \mathrm{L}$ reaction mixture containing $1 \times$ KAPA2G Robust HotStart ReadyMix with dye (KAPA Biosystems, Wilmington, MA, USA), $0.5 \mu \mathrm{M}$ of each primer, and $1 \mu \mathrm{L}$ DNA template. The PCR protocol for each round consisted of an initial denaturation at $95^{\circ} \mathrm{C}$ for $2 \mathrm{~min}, 30$ cycles of denaturation at $95^{\circ} \mathrm{C}$ for $90 \mathrm{~s}$, annealing at $54^{\circ} \mathrm{C}$ for $10 \mathrm{~s}$, extension at $72^{\circ} \mathrm{C}$ for $30 \mathrm{~s}$, and a final extension at $72^{\circ} \mathrm{C}$ for $2 \mathrm{~min}$. The second-round PCR products were cloned into the T-vector pMD20 (Takara Bio, Shiga, Japan) using the TaKaRa DNA Ligation Kit Mighty Mix and Escherichia coli HST08 Premium Competent Cells (TaKaRa Bio) according to the manufacturer's instructions. Each recombinant $E$. coli colony was randomly selected and boiled in $30 \mu \mathrm{L}$ sterile water for $10 \mathrm{~min}$ at $98^{\circ} \mathrm{C}$. DNA fragments were amplified from the supernatant by PCR using a primer specific to the vector. The PCR products were purified using the Illustra ExoProStar system (GE Healthcare, Chicago, IL, USA) according to the manufacturer's instructions, and sequenced by Macrogen Japan Co. (Tokyo, Japan). Eight colonies were sequenced from each root sample that showed positive results following amplification.

\section{Data analysis and phylogeny}

Nucleotide sequences received from Macrogen Japan were cleaned and submitted to the CD-HIT Suite online tool (Huang et al., 2010) for operational taxonomic Unit (OTU) clustering. OTU clusters were formed at $99 \%$ similarity. Non-AMF OTUs were removed from the data, and the most representative OTU cluster sequences were blasted using the MEGA-X web service menu (Kumar et al., 2018). Additional sequences of the LSU region of other glomeromycotan species were added to the data, and sequences were aligned using the Muscle alignment tool of MEGA-X. The sequences of OTUs generated in this study are available in the National Center for Biotechnology Information (NCBI) GenBank database (links are provided in the Data Availability section).

Evolutionary history was inferred using a maximum likelihood (ML)-based general time reversible model (Nei and Kumar, 2000), and the neighbor-joining (NJ) method (Saitou and Nei, 1987) with the MEGA-X software (Kumar et al., 2018). For the first method, initial trees for the heuristic search were obtained automatically by applying NJ and BioNJ algorithms to a matrix of pairwise distances estimated using the maximum composite likelihood approach, and then selecting the topology with the highest log likelihood value. A discrete gamma distribution was used to model evolutionary rate 
differences among sites $(5$ categories $+\mathrm{G}$, parameter $=1.0112)$. In the second method, evolutionary distances were computed using the p distance method (Nei and Kumar, 2000) and expressed as numbers of base differences per site. These analyses involved 83 nucleotide sequences including 39 OTUs obtained in this study; all sequences are available in the GenBank database. We eliminated all positions with less than $95 \%$ site coverage using the partial deletion option. In total, 301 positions were included in the final dataset. The ML model tree with the highest log likelihood value (-5161.09) is shown. The tree was outgrouped with Paraglomus occultum FJ461883, drawn to scale, with branch lengths measured in terms of the number of substitutions per site. For each model, the percentage of trees in which the associated taxa clustered together in a bootstrap test (Felsenstein, 1985) with 1000 replicates is shown next to each branch (NJ/ML).

\section{Statistical analysis}

Differences in colonization intensity between species were tested using one-way analysis of variance (ANOVA), and means were compared using Tukey's honestly significant difference (HSD) test with the R v. 3.5.2 software (R Core Team, 2016).

\section{Results}

Mycorrhizas were present in the roots of all of the sampled trees, but at different intensities (Fig. 2, Table 1); intensity was higher in E. africana $(84 \pm 19 \%)$ than in P. erinaceus $(48 \pm 24 \%)$ and $A$. africana $(48 \pm 30 \%)$. There were no significant differences in the intensity of mycorrhizal colonization between $P$. erinaceus and A. africana.

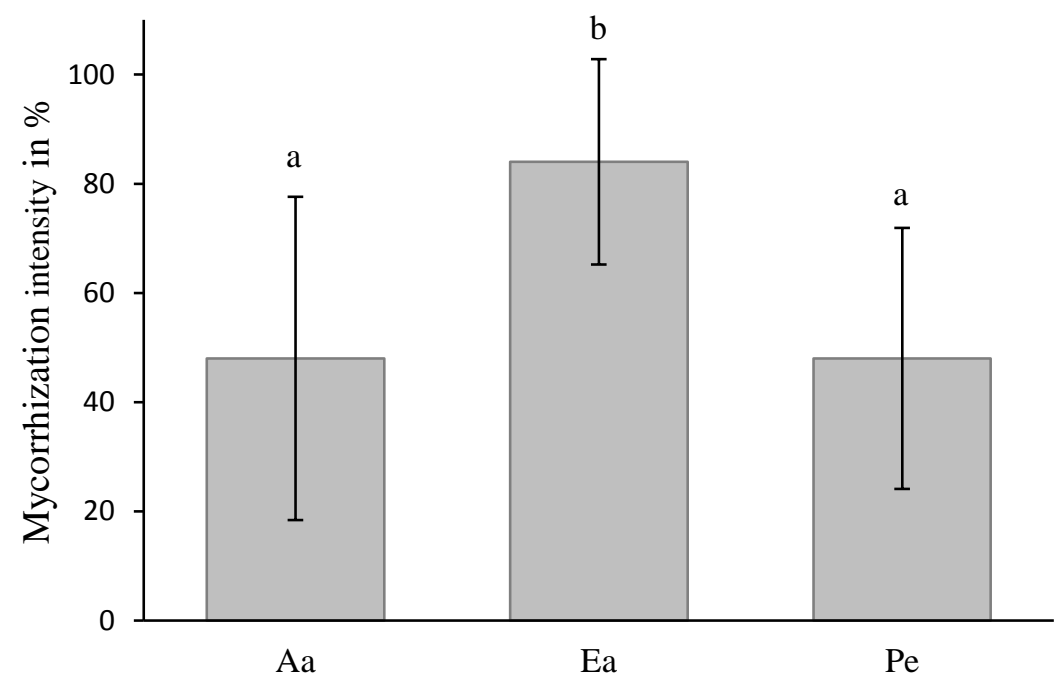

Figure 2. Mycorrhizal colonization intensity (mean \pm standard error) in roots of three tree species. Identical letters indicate no significant difference among the tested species (Tukey's honest significant difference [HSD] test, $p<0.05 ; n=5$ ). Aa, Afzelia africana; Ea, Entada africana; $\mathrm{Pe}$, Pterocarpus erinaceus 
Table 1. One-way analysis of variance table for the intensity of mycorrhizal colonization (AMF\%). The factor "Species" has 3 levels (Afzelia africana, Entada africana, and Pterocarpus erinaceus). AMF\% is significantly different among species

\begin{tabular}{c|c|c|c|c|c}
\hline Factor & Df & Sum Sq & Mean Sq & F value & $\operatorname{Pr}(>\mathbf{F})$ \\
\hline Species & 2 & 4320 & 2160 & 5.5385 & $0.01977^{*}$ \\
Residuals & 12 & 4680 & 390 & & \\
\hline
\end{tabular}

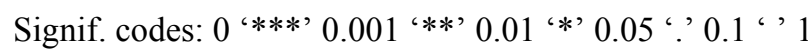

We found vesicles, arbuscules, and intra- and intercellular hyphae in stained roots of A. africana, E. africana, and P. erinaceus (Fig. 3). We detected 39 AMF OTUs, including 9 from A. africana, 18 from E. africana, and 15 from $P$. erinaceus. Three OTUs (1, 8, and 15) were present in two tree species, whereas the others were species-specific (Table 2).
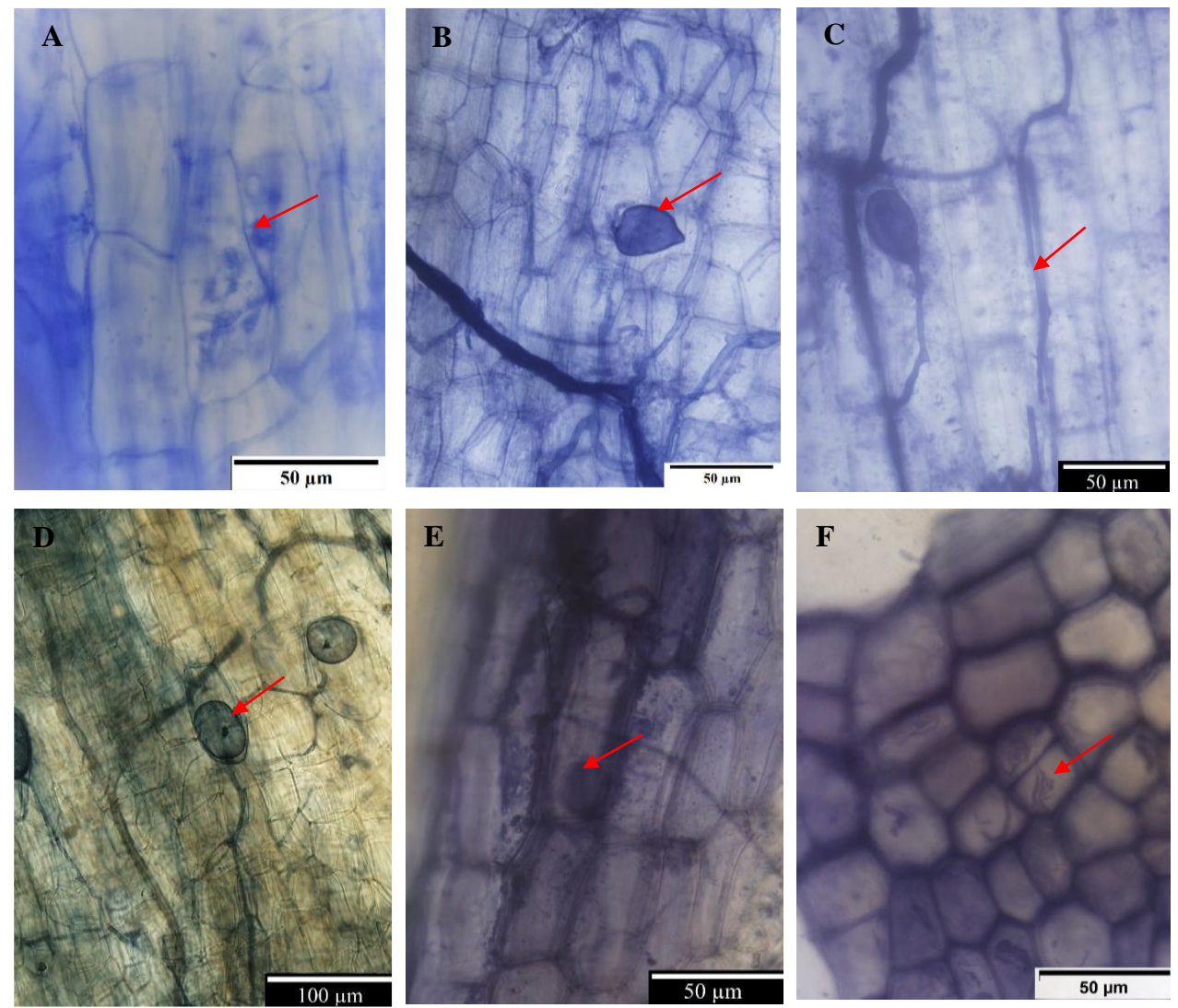

Figure 3. Micrographs of trypan blue-stained roots taken with an Olympus DP71 camera fitted to an Olympus BX50 microscope. Arrows indicate finely branched arbuscules (A) and terminal vesicles $(B)$ in roots of $A$. africana, intercellular hyphae $(C)$ and terminal vesicles $(D)$ in roots of $\mathrm{E}$. africana, and non-terminal vesicles $(E)$ and intercellular hyphae $(F)$ in roots of $\mathrm{P}$. erinaceus

Using a threshold of percentage of identity equal to or greater than $95 \%$, we identified OTUs 2, 14, 15, and 31 as Scutellospora erythropa (in E. africana), Rhizoglomus dalpeae (in E. africana), Septoglomus deserticola (in A. africana), and Glomus trimurales (in E. africana), respectively (Table 2). 
Table 2. Glomeromycotan operational taxonomic units (OTUs) detected in this study, ordered by their presence and abundance in all three tree host species

\begin{tabular}{|c|c|c|c|c|c|c|c|c|c|c|}
\hline \multirow{2}{*}{ OTUs } & \multicolumn{4}{|c|}{ OTUs Freq (\%) } & \multirow{2}{*}{ Access no. } & \multicolumn{5}{|c|}{ Closest BLAST match } \\
\hline & Aa & $\mathbf{E a}$ & $\mathbf{P e}$ & All species & & Score & e value & Access no. & Identity (\%) & Species \\
\hline 1 & 42 & 0 & 8 & 14 & MN920713 & 652 & 0 & GQ149222 & 98.13 & uncultured Glomeromycotina \\
\hline 2 & 0 & 13 & 0 & 5 & MN920719 & 551 & $1.00 \mathrm{E}-152$ & AM086173 & 98.71 & Scutellospora erythropa \\
\hline 3 & 21 & 0 & 0 & 5 & MT408134 & 654 & $0.00 \mathrm{E}+00$ & HG515449 & 98.91 & uncultured Glomeromycotina \\
\hline 4 & 0 & 0 & 17 & 5 & MT408150 & 616 & 3.38E-172 & HE858414 & 96.28 & uncultured Glomus \\
\hline 5 & 0 & 10 & 0 & 4 & MN920715 & 580 & $1.00 \mathrm{E}-161$ & MH504073 & 94.71 & uncultured Sclerocystis \\
\hline 6 & 0 & 10 & 0 & 4 & MN920717 & 610 & $2.00 \mathrm{E}-170$ & MH504060 & 96.04 & uncultured Sclerocystis \\
\hline 7 & 0 & 10 & 0 & 4 & MT408139 & 628 & 4.32E-176 & MH504023 & 97.07 & uncultured Sclerocystis \\
\hline 8 & 0 & 3 & 8 & 4 & MT408144 & 462 & $4.67 \mathrm{E}-126$ & JF798534 & 90.42 & uncultured Glomeromycotina \\
\hline 9 & 0 & 0 & 13 & 4 & MT408154 & 660 & $0.00 \mathrm{E}+00$ & HG515449 & 99.18 & uncultured Glomeromycotina \\
\hline 10 & 0 & 0 & 8 & 3 & MN920710 & 632 & $4.00 \mathrm{E}-177$ & HE858414 & 97.07 & uncultured Glomerales \\
\hline 11 & 0 & 6 & 0 & 3 & MN920712 & 612 & $5.00 \mathrm{E}-171$ & MH504023 & 96.28 & uncultured Sclerocystis \\
\hline 12 & 0 & 6 & 0 & 3 & MN920714 & 606 & $2.00 \mathrm{E}-169$ & KM879707 & 95.99 & uncultured Glomeromycotina \\
\hline 13 & 0 & 6 & 0 & 3 & MN920716 & 588 & $9.00 \mathrm{E}-164$ & HQ857172 & 95.17 & uncultured fungus \\
\hline 14 & 0 & 6 & 0 & 3 & MN920718 & 682 & 0 & MN130954 & 99.73 & Rhizoglomus dalpeae \\
\hline 15 & 5 & 0 & 4 & 3 & MT408133 & 592 & $5.65 \mathrm{E}-165$ & JQ048925 & 95.21 & Septoglomus deserticola \\
\hline 16 & 0 & 0 & 8 & 3 & MT408149 & 588 & 7.27E-164 & GQ149222 & 95.19 & uncultured Glomeromycotina \\
\hline 17 & 0 & 0 & 4 & 1 & MN920708 & 645 & 0 & HG515449 & 98.90 & uncultured Glomeromycota \\
\hline 18 & 0 & 0 & 4 & 1 & MN920709 & 466 & $4.00 \mathrm{E}-127$ & JF798534 & 90.50 & Glomus sp. \\
\hline 19 & 0 & 3 & 0 & 1 & MN920711 & 588 & $9.00 \mathrm{E}-164$ & JQ048925 & 94.96 & Septoglomus deserticola \\
\hline 20 & 5 & 0 & 0 & 1 & MN920720 & 523 & $3.00 \mathrm{E}-144$ & GQ149222 & 92.25 & uncultured Glomeromycotina \\
\hline 21 & 5 & 0 & 0 & 1 & MT408132 & 641 & $5.57 \mathrm{E}-180$ & GQ149222 & 97.59 & uncultured Glomeromycotina \\
\hline 22 & 5 & 0 & 0 & 1 & MT408135 & 652 & $0.00 \mathrm{E}+00$ & HG515449 & 98.91 & uncultured Glomeromycotina \\
\hline 23 & 5 & 0 & 0 & 1 & MT408136 & 518 & $9.56 \mathrm{E}-143$ & GQ149222 & 91.98 & uncultured Glomeromycotina \\
\hline 24 & 5 & 0 & 0 & 1 & MT408137 & 551 & $9.42 \mathrm{E}-153$ & GQ149222 & 93.58 & uncultured Glomeromycotina \\
\hline 25 & 5 & 0 & 0 & 1 & MT408138 & 641 & $5.57 \mathrm{E}-180$ & GQ149222 & 97.59 & uncultured Glomeromycotina \\
\hline
\end{tabular}




\begin{tabular}{|c|c|c|c|c|c|c|c|c|c|c|}
\hline \multirow{2}{*}{ OTUs } & \multicolumn{4}{|c|}{ OTUs Freq $(\%)$} & \multirow{2}{*}{ Access no. } & \multicolumn{5}{|c|}{ Closest BLAST match } \\
\hline & Aa & $\mathbf{E a}$ & $\mathbf{P e}$ & All species & & Score & e value & Access no. & Identity (\%) & Species \\
\hline 26 & 0 & 3 & 0 & 1 & MT408140 & 617 & $9.35 \mathrm{E}-173$ & MH504023 & 96.53 & uncultured Sclerocystis \\
\hline 27 & 0 & 3 & 0 & 1 & MT408141 & 580 & $1.23 \mathrm{E}-161$ & MH504073 & 94.71 & uncultured Sclerocystis \\
\hline 28 & 0 & 3 & 0 & 1 & MT408142 & 586 & $2.64 \mathrm{E}-163$ & MH504073 & 94.97 & uncultured Sclerocystis \\
\hline 29 & 0 & 3 & 0 & 1 & MT408143 & 575 & $5.71 \mathrm{E}-160$ & MH504073 & 94.44 & uncultured Sclerocystis \\
\hline 30 & 0 & 3 & 0 & 1 & MT408145 & 595 & $4.38 \mathrm{E}-166$ & MH504023 & 95.47 & uncultured Sclerocystis \\
\hline 31 & 0 & 3 & 0 & 1 & MT408146 & 636 & $2.56 \mathrm{E}-178$ & JN937265 & 97.58 & Glomus trimurales \\
\hline 32 & 0 & 3 & 0 & 1 & MT408147 & 566 & $3.45 \mathrm{E}-157$ & JQ048925 & 93.90 & Septoglomus deserticola \\
\hline 33 & 0 & 3 & 0 & 1 & MT408148 & 531 & $1.00 \mathrm{E}-146$ & HG515434 & 92.88 & uncultured Glomeromycotina \\
\hline 34 & 0 & 0 & 4 & 1 & MT408151 & 652 & $0.00 \mathrm{E}+00$ & HG515449 & 98.91 & uncultured Glomeromycotina \\
\hline 35 & 0 & 0 & 4 & 1 & MT408152 & 649 & $0.00 \mathrm{E}+00$ & HG515449 & 98.63 & uncultured Glomeromycotina \\
\hline 36 & 0 & 0 & 4 & 1 & MT408153 & 652 & $0.00 \mathrm{E}+00$ & HG515449 & 98.91 & uncultured Glomeromycotina \\
\hline 37 & 0 & 0 & 4 & 1 & MT408155 & 652 & $0.00 \mathrm{E}+00$ & HG515449 & 98.91 & uncultured Glomeromycotina \\
\hline 38 & 0 & 0 & 4 & 1 & MT408156 & 660 & $0.00 \mathrm{E}+00$ & HG515449 & 99.18 & uncultured Glomeromycotina \\
\hline 39 & 0 & 0 & 4 & 1 & MT408157 & 649 & 0 & HG515449 & 98.63 & uncultured Glomeromycotina \\
\hline Total & 100 & 100 & 100 & 100 & & & & & & \\
\hline
\end{tabular}

Aa, Afzelia africana; Ea, Entada africana; Pe, Pterocarpus erinaceus 
Phylogenetic groups based on consensus trees and $80 \%$ bootstrap replicates revealed 3 genera (Nanoglomus, Rhizoglomus, and Septoglomus) in roots of A. africana; 4 genera (Rhizoglomus, Scutellospora, Nanoglomus, and Septoglomus) in the roots of E. africana; and 4 genera (Glomus, Rhizoglomus, Sclerocystis, and Nanoglomus) in roots of P. erinaceus (Fig. 4). Overall, phylogenetic inference classified 39 OTUs among which 2 (OTUs 8, and 18) were unidentified at the genus level, in the Glomeraceae, and only one OTU, which was identified as Scutellospora erythropa, in the Gigasporaceae.

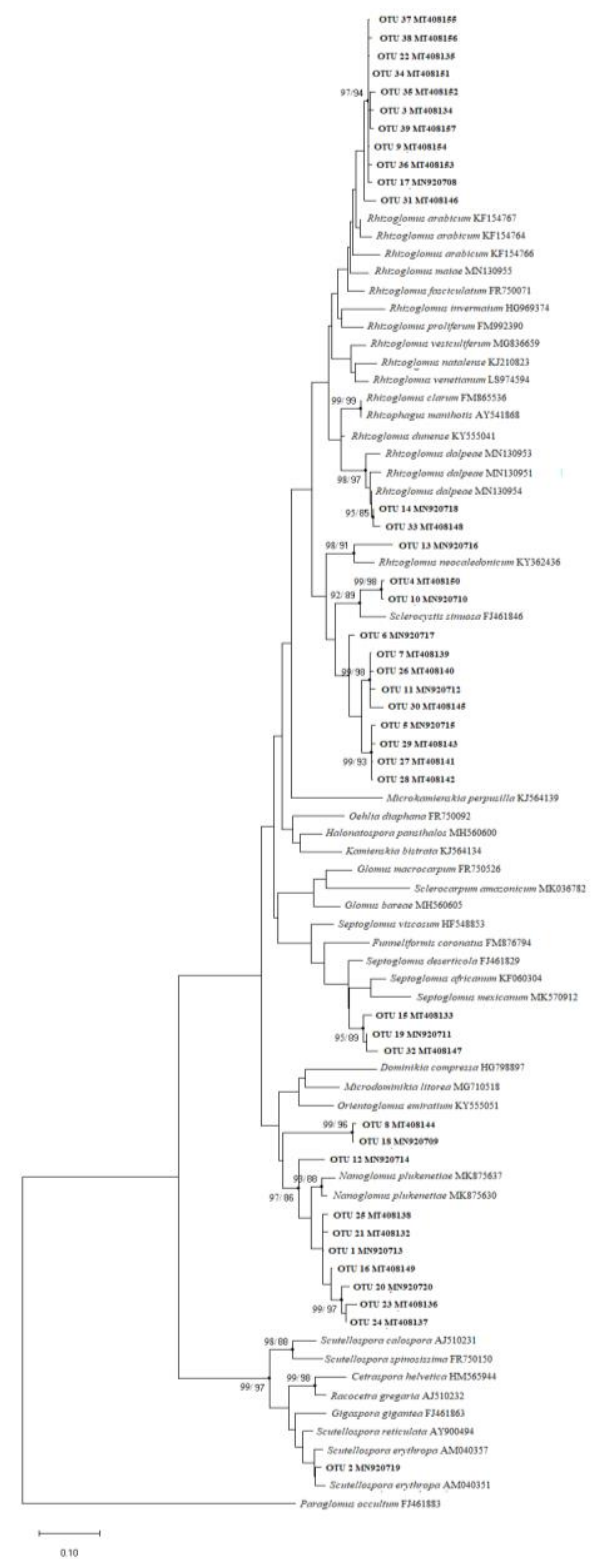

Figure 4. Maximum likelihood (ML) phylogenetic tree obtained following analyses of large subunit (LSU) sequence data from arbuscular mycorrhizal fungi $(A M F)$ in roots of A. africana, E. africana, and P. erinaceus sampled in Benin. The ML tree was constructed using a general time-reversible model assuming a discrete gamma distribution. Paraglomus occultum FJ461883 was used as an outgroup. Neighbor-joining (NJ) and ML bootstrap values $\geq 80 \%$ (NJ/ML) are provided at nodes marked with black dots. Operational taxonomic units (OTUs) generated in this study are indicated as OTU\#; the scientific names of downloaded OTUs are indicated, followed by their accession numbers 


\section{Discussion}

To the best of our knowledge, this study is the first to report microscopic and molecular evidence of arbuscular mycorrhiza in roots of A. africana, E. africana, and P. erinaceus in their natural habitats. Structurally, E. africana showed the highest intensity of mycorrhizal colonization. Our basic local alignment search and phylogeny analyses revealed Nanoglomus spp., Rhizoglomus spp., and Septoglomus sp. as putative AMF in the roots of A. africana. Rhizoglomus spp., Scutellospora sp., Nanoglomus spp., Septoglomus spp., and one genus-unidentified Glomeraceaous species (OTU 8) were putative AMF in the roots of E. africana, whereas those found in the roots of $P$. erinaceus were Glomus sp., Rhizoglomus spp., Sclerocystis spp., Nanoglomus sp., and one genusunidentified Glomeraceaous species (OTU 18).

A critical review (Brundrett, 2009) emphasized past misdiagnosis related to the types of mycorrhizal features used during identification of mycorrhiza. McGonigle et al. (1990) recommended caution in the use of hyphae and vesicles, because unlike arbuscules, these features can appear sporadically in some non-mycorrhizal species. In the present study, we relied not only on the observation of morphological characteristics such as arbuscules, vesicles, and intra- and intercellular hyphae in stained roots, but also on DNA analyses. We also referred to illustrations of morphological features (Yuan et al., 2011; Priyadharsini et al., 2012; Claassens et al., 2018) to confirm features observed in our micrographs.

Some LSU sequences generated in the current study matched uncultured arbuscular mycorrhizal (AM) species according to the Basic Local Alignment Search Tool (BLAST), indicating a lack of molecular and mycological data on the tropical AMF community. This lack of data may also explain the positions of two OTUs on the phylogenetic tree, which corresponded to Glomeraceaous species but were not identified to the genus level.

Most OTUs (38 of 39) belonged to Glomeraceae, whereas only one belonged to Gigasporaceae. This result is consistent with a previous review of AMF species in tropical forests, which described Glomeraceae (78 of 228 species) as the most dominant family and Gigasporaceae (6 of 228 species) as one of the least represented families (Marinho et al., 2018). Rhizoglomus dalpeae, recently described by Błaszkowski et al. (2019) in Benin as a new species, was identified from roots of E. africana. The host tree in our study was collected from an inselberg within the Wari Maro forest reserve. The habitat within this reserve is a harsh environment, similar to the location where the fungus described by Błaszkowski et al. (2019) was collected.

Thoen and $\mathrm{Ba}$ (1989) reported that A. africana is ectomycorrhizal but is not associated with any endomycorrhiza. The same authors evaluated $A$. africana seed germination and seedling infection, and found that its seedlings exhibit early ectomycorrhizal infection. Yorou et al. (2008) also described the formation of ectomycorrhiza between A. africana and Tomentella species; however, they did not discuss its arbuscular mycorrhizal status. In the present study, we applied morphological and molecular methods to confirm that A. africana roots contained AMF, and therefore hypothesize that this species may be dual-mycorrhizal. In our study, all sampled A. africana individuals were adult trees, implying that arbuscular mycorrhiza are formed in adult trees of this species. In addition, Thoen and Ba (1989) conducted their research in Senegal, whereas our study was conducted in Benin. Dual mycorrhizae have been reported in West Africa for Afzelia pachyloba Harms, Gilbertiodendron dewevrei (De Wild.) J. Leonard, Uapaca guineensis Müll. Arg., and Uapaca staudtii Pax (Newbery et al., 1988; Thoen and Ba, 1989). 
Therefore, we agree with the claim of Thoen and $\mathrm{Ba}$ (1989) that roots of adult individual trees should also be examined to avoid erroneous conclusions, because dual mycorrhizal colonization may be more common than previously thought. The high resistance to harsh environmental conditions shown by $A$. africana may be explained by such dual mycorrhizal colonization. We could not identify the Nanoglomus fungus found in roots of $A$. africana to the species level; however, its arbuscules and terminal vesicles were comparable to those reported by Corazon-Guivin et al. (2019) describing Nanoglomus plukenetiae as new fungal species.

AMF colonization intensity and the number of OTUs were higher in E. africana roots than in those of $A$. africana and $P$. erinaceus. The high mycorrhizal dependency of this species may be explained by its ecology. All sampled E. africana individuals were growing on shallow and rocky soils of an inselberg, where the absorption of soil resources may be difficult without fungal associations. $R$. dalpeae was previously found to originate from an inselberg with severe environmental conditions in Benin (Błaszkowski et al., 2019), an environment like the one of our research site. The association between $E$. africana and $R$. dalpeae as a mycorrhizal fungal partner could explain the adaptation strategies of the plant to such a harsh environment. A previous study (Tamilarasi et al., 2008) suggested that rhizosphere microorganisms influence the antibacterial properties of medicinal plants; the effects of AMF colonization on medicinal properties should be examined in E. africana, which is a medicinal tree species that contains many types of phytochemical compounds (Sanogo et al., 1998; Ahua et al., 2007; Tibiri et al., 2007, 2010; Mbatchou et al., 2011).

Because P. erinaceus is a slow-growing species (Dumenu and Bandoh, 2016), it is not used in plantations, and its overexploitation in natural forests is causing a gradual decline in its population (Barstow, 2018). In 2016, to prevent its extinction from natural habitats, as has occurred in other African countries, the Government of Benin banned the logging and export of $P$. erinaceus to China, India, and other countries. Previous studies have reported mycorrhizae in $P$. angolensis DC. (Hengari et al., 2004), P. soyauxii Taub. (Onguene et al., 2011), P. marsupium Roxb. (Verma et al., 2016), and P. officinalis (Saint-Etienne et al., 2006; Fougnies et al., 2007) but not in P. erinaceus. The current study reports the first evidence that $P$. erinaceus can form arbuscular mycorrhizae, which may be exploited to improve P. erinaceus growth in West Africa.

\section{Conclusion}

This study was the first to examine AMF in the roots of three valuable tropical forest tree species in their natural habitats. We confirmed that A. africana, E. africana, and P. erinaceus are all AMF host trees species. E. africana showed a relatively high dependence on AMF. At a genus level, 3 genera were identified in A. africana, and 4 in E. africana and P. erinaceus. At a species level, Glomus trimurales, Scutellospora erythropa, and Rhizoglomus dalpeae were identified from the roots of E. africana, and Septoglomus deserticola from the roots of A. africana. Our findings represent a theoretical basis for future applications of mycorrhizal technologies to improve the recruitment and growth of these three tree species following germination of seeds in a controlled environment. Future researches should examine the contribution of AMF to the resistance of $A$. africana in harsh environmental conditions, the effects of AMF colonization on medicinal properties in E. africana, and the potential growth-promoting activities of AMF in P. erinaceus. 
Acknowledgements. We thank M. AGOKOLI and forest officers AKINDELE and YEVIDE for their support during our data collection efforts in Benin.

Author contributions. The first author conducted this work under the supervision of the co-authors.

Competing interests. The authors declare that they have no competing interests.

Data availability. The complete sequences generated in this study are available in the GenBank database at the following websites: https://submit.ncbi.nlm.nih.gov/subs/?search=SUB6744268 and https://submit.ncbi.nlm.nih.gov/subs/?search=SUB7335363.

\section{REFERENCES}

[1] Adjonou, K., Ali, N., Kokutse, A. D., Novigno, S. K. (2010): Etude de la dynamique des peuplements naturels de Pterocarpus erinaceus Poir. (Fabaceae) surexploités au Togo. Bois et Forêts Des Tropiques, CIRAD (Centre de Cooperation Internationale en Recherche Agronomique Pour le Developpement) 306(4): 45-55.

[2] African Regional Workshop (1998): Afzelia africana. - Conservation \& sustainable management of trees Zinbabwe July 1996, The IUCN Red List of Threatened Species 1998: e.T33032A9751552, available at: https://doi.org/https://dx.doi.org/10.2305/IUCN.UK.1998.RLTS.T33032A9751552.en.

[3] Aggarwal, A., Kadian, N., Tanwar, A., Yadav, A., Gupta, K. K. (2011): Role of arbuscular mycorrhizal fungi (AMF) in global sustainable development. - Journal of Applied and Natural Science 3(2): 340-351.

[4] Ahua, K. M., Ioset, J. R., Ioset, K. N., Diallo, D., Mauël, J., Hostettmann, K. (2007): Antileishmanial activities associated with plants used in the Malian traditional medicine. Journal of Ethnopharmacology 110(1): 99-104.

[5] Aubréville, A. (1970): Flore du Cameroon: Légumineuses Ceasalpinoidées. - Muséum national d'histoire naturelle Laboratoire de phanérogamie, Paris.

[6] Ba, A. M., Thoen, D. (1990): First syntheses of ectomycorrhizas between Afzelia africana Sm. (Caesalpinioideae) and native fungi from West Africa. - New Phytologist 114(1): 99103.

[7] Barstow, M. (2018): Pterocarpus erinaceus. - The IUCN Red List of Threatened Species 2018: e.T62027797A62027800.

[8] Bationo, B. A., Ouedraogo, S. J., Guinko, S. (2001): Longévité des graines et contraintes à la survie des plantules d' Afzelia africana Sm. dans une savane boisée du Burkina Faso. Annals of Forest Science 58(1): 69-75.

[9] Bayer, W., Waters-Bayer, A. (1999): La Gestion Des Fourrages. - CTA, Wageningen, The Netherlands.

[10] Błaszkowski, J., Niezgoda, P., Piątek, M., Magurno, F., Malicka, M., Zubek, S., Mleczko, P., Yorou, N. S., Jobim, K., Vista, X. M., Lima, J. L. R., Goto, B. T. (2019): Rhizoglomus dalpeae, $R$. maize, and $R$. silesianum, new species. - Mycologia 111(6): 965-980.

[11] Botanic Gardens Conservation International and International Union for Conservation of Nature SSC Global Tree Specialist Group. (2019): Entada africana. - The IUCN Red List of Threatened Species 2019: e.T144292247A14902860.

[12] Brundrett, M. (2004): Diversity and classification of mycorrhizal associations. - Biological Reviews 79 (3): 473-495.

[13] Brundrett, M. C. (2009): Mycorrhizal associations and other means of nutrition of vascular plants: understanding the global diversity of host plants by resolving conflicting information and developing reliable means of diagnosis. - Plant and Soil 320: 37-77.

[14] Brundrett, M. C., Piché, Y., Peterson, R. L. (1984): A new method for observing the morphology of vesicular-arbuscular mycorrhizae. - Canadian Journal of Botany 62(10): 2128-2134. 
[15] Bücking, H., Kafle, A. (2015): Role of arbuscular mycorrhizal fungi in the nitrogen uptake of plants: current knowledge and research gaps. - Agronomy 5(4): 587-612.

[16] Bunn, R. A., Simpson, D. T., Bullington, L. S., Lekberg, Y., Janos, D. P. (2019): Revisiting the 'direct mineral cycling' hypothesis: arbuscular mycorrhizal fungi colonize leaf litter, but why? - ISME Journal 13(8): 1891-1898.

[17] Claassens, A., Nock, C. J., Rose, M. T., van Zwieten, L., Rose, T. J. (2018): Colonisation dynamics of arbuscular mycorrhizal fungi and dark septate endophytes in the sugarcane crop cycle. - Rhizosphere 7: 18-26.

[18] Clark, R. B., Zeto, S. K. (2000): Mineral acquisition by arbuscular mycorrhizal plants. Journal of Plant Nutrition 23(7): 867-902.

[19] Corazon-Guivin, M. A., Cerna-Mendoza, A., Guerrero-Abad, J. C., Vallejos-Tapullima, A., Carballar-Hernández, S., da Silva, G. A., Oehl, F. (2019): Nanoglomus plukenetiae, a new fungus from Peru, and a key to small-spored Glomeraceae species, including three new genera in the 'Dominikia complex/clades'. - Mycological Progress 18(12): 13951409.

[20] Dar, Z. M., Masood, A., Asif, M., Malik, M. A. (2018): Review on arbuscular mycorrhizal fungi: an approach to overcome drought adversities in plants. - International Journal of Current Microbiology and Applied Sciences 7(3): 1040-1049.

[21] DIVA-GIS. (2018): Free geographic (GIS) data for any country in the world. Administrative areas data for Benin. - Available at: www.diva-gis.org/datadown (accessed 13 March 2018).

[22] Djotan, A. K. G., Aoudji, K. N. A., Codjia, A. F. S., Gbètoho, A. J., Koura, K., Ganglo, J. C. (2018): How far can climate changes help to conserve and restore Garcinia kola Heckel, an extinct species in the wild in Benin (West Africa). - International Journal of Biodiversity and Conservation 10(5): 203-213.

[23] Dumenu, W. K. (2019): Assessing the impact of felling/export ban and CITES designation on exploitation of African rosewood (Pterocarpus erinaceus). - Biological Conservation 236: 124-133.

[24] Dumenu, W. K., Bandoh, W. N. (2016): Exploitation of African rosewood (Pterocarpus erinaceus) in Ghana: a situation analysis. - Ghana Journal of Forestry 32: 1-15.

[25] Felsenstein, J. (1985): Confidence limits on phylogenies: an approach using the bootstrap. - Evolution 39(4): 783-791.

[26] Fougnies, L., Renciot, S., Muller, F., Plenchette, C., Prin, Y., de Faria, S. M., Bouvet, J. M., Sylla, S. Nd., Dreyfus, B., Ba, A. M. (2007): Arbuscular mycorrhizal colonization and nodulation improve flooding tolerance in Pterocarpus officinalis Jacq. seedlings. Mycorrhiza 17(3): 159-166.

[27] Fujimaki, R., Tateishi, T., Kohzu, A., Saito, M., Tokuchi, N. (2001): Characterization of arbuscular mycorrhizal colonization of 4 plant species in a Japanese red cedar plantation. - Soil Microorganisms 55(2): 121-128.

[28] Giovannetti, M., Mosse, B. (1980): An evaluation of techniques for measuring vesicular arbuscular mycorrhizal infection in roots. - New Phytologist 84(3): 489-500.

[29] Gollotte, A., van Tuinen, D., Atkinson, D. (2004): Diversity of arbuscular mycorrhizal fungi colonising roots of the grass species Agrostis capillaris and Lolium perenne in a field experiment. - Mycorrhiza 14(2): 111-117.

[30] Hengar, S. N., Valentine, A. J., Theron, J. M. (2004): The effect of the colonisation extent of arbuscular mycorrhizal fungi on the growth of pot grown Pterocarpus angolensis seedlings. - Southern African Forestry Journal 202(1): 13-20.

[31] Houehanou, T. D., Prinz, K., Hellwig, F., Assogbadjo, A. E., Gebauer, J., Glele Kakaï, R. L., Sinsin, B. (2019): Morphological trait variation and relationships of Afzelia africana Sm. caused by climatic conditions and anthropogenic disturbance in Benin (West Africa). - Genetic Resources and Crop Evolution 66(5): 1091-1105.

[32] Huang, Y., Niu, B., Gao, Y., Fu, L., Li, W. (2010): CD-HIT Suite: a web server for clustering and comparing biological sequences. - Bioinformatics 26(5): 680-682. 
[33] Kumar, S., Stecher, G., Li, M., Knyaz, C., Tamura, K. (2018): MEGA X: Molecular Evolutionary Genetics Analysis across computing platforms. - Molecular Biology and Evolution 35(6): 1547-1549.

[34] Makoi, J., Ndakidemi, P. (2009): The agronomic potential of vesicular-arbuscular mycorrhiza (VAM) in cereals-legume mixtures in Africa. - African Journal of Microbiology Research 3(11): 664-675.

[35] Marinho, F., da Silva, I. R., Oehl, F., Maia, L. C. (2018): Checklist of arbuscular mycorrhizal fungi in tropical forests. - Sydowia 70: 107-127.

[36] Mbatchou, V. C., Ayebila, A. J., Apea, O. B. (2011): Antibacterial activity of phytochemicals from Acacia nilotica, Entada africana, and Mimosa pigra L. on Salmonella typhi. - Journal of Animal \& Plant Sciences 10(1): 1248-1258.

[37] McGonigle, T. P., Miller, M. H., Evans, D. G., Fairchild, G. L., Swan, J. A. (1990): A new method which gives an objective measure of colonization of roots by vesicular-arbuscular mycorrhizal fungi. - New Phytologist 115(3): 495-501.

[38] Nei, M., Kumar, S. (2000): Molecular evolution and phylogenetics. - Oxford University Press, New York.

[39] Newbery, D. M., Alexander, I. J., Thomas, D. W., Gartlan, J. S. (1988): Ectomycorrhizal rain-forest legumes and soil phosphorus in Korup National Park, Cameroon. - New Phytologist 109(4): 433-450.

[40] Olafadehan, O. A. (2013): Feeding value of Pterocarpus erinaceus for growing goats. Animal Feed Science and Technology 185(1-2): 1-8.

[41] Onguene, N. A., Ngonkeu, L. E. M., Kuyper, T. W. (2011): Growth response of Pterocarpus soyauxii and Lophira alata seedlings to host soil mycorrhizal inocula in relation to land use types. - African Journal of Microbiology Research 5(17): 2391-2398.

[42] Padonou, E. A., Kassa, B., Assogbadjo, A. E., Chakeredza, S., Babatoundé, B., Glèlè Kakaï, R. (2013): Differences in germination capacity and seedling growth between different seed morphotypes of Afzelia africana Sm. in Benin (West Africa). - Journal of Horticultural Science and Biotechnology 88(6): 679-684.

[43] Phillips, J. M., Hayman, D. S. (1970): Improved procedures for clearing roots and staining parasitic and vesicular-arbuscular mycorrhizal fungi for rapid assessment of infection. Transactions of the British Mycological Society 55(1): 158-161.

[44] Priyadharsini, P., Muthukumar, T., Pandey, R. R. (2012): Arbuscular mycorrhizal and dark septate fungal associations in shallot (Allium cepa L. var. aggregatum) under conventional agriculture. - Acta Botanica Croatica 71(1): 159-175.

[45] R Core Team. (2016): R: a language and environment for statistical computing. - R Foundation for Statistical Computing, Vienna, available at: www. R-proje ct. org.

[46] Rabiou, H., Bationo, B., Segla, K., Diouf, A., Adjonou, K., Kokutse, A., Radji, R., Mahamane, A., Kokou, K., Saadou, M. (2015): Estimation de volume commercial du bois de Pterocarpus erinaceus Poir. (Fabaceae) dans les zones sahélo-soudaniennes et Soudaniennes du Niger et du Burkina Faso (Afrique de l'ouest). - Journal of Applied Biosciences 87: 8131-8143.

[47] Redhead, J. F. (1968): Mycorrhizal associations in some Nigerian forest trees. Transactions of the British Mycological Society 51(3-4): 377-387.

[48] Saint-Etienne, L., Paul, S., Imbert, D., Dulormne, M., Muller, F., Toribio, A., Plenchette, C., Ba, A. M. (2006): Arbuscular mycorrhizal soil infectivity in a stand of the wetland tree Pterocarpus officinalis along a salinity gradient. - Forest Ecology and Management 232(13): 86-89.

[49] Saitou, N., Nei, M. (1987): The neighbor-joining method: a new method for reconstructing phylogenetic trees. - Molecular Biology and Evolution 4(4): 406-425.

[50] Salako, V. K., Fandohan, B., Kassa, B., Assogbadjo, A. E., Idohou, A. F. R., Gbedomon, R. C., Chakeredza, S., Dulloo, M. E., Kakai, R. G. (2014): Home gardens: an assessment of their biodiversity and potential contribution to conservation of threatened species and crop wild relatives in Benin. - Genetic Resources and Crop Evolution 61(2): 313-330. 
[51] Sanogo, R., Germanò, M. P., D’Angelo, V., Guglielmo, M., de Pasquale, R. (1998): Antihepatotoxic properties of Entada africana (Mimosaceae). - Phytotherapy Research 12(S1): 157-159.

[52] Sbrana, C., Avio, L., Giovannetti, M. (2014): Beneficial mycorrhizal symbionts affecting the production of health-promoting phytochemicals. - Electrophoresis 35(11): 1535-1546.

[53] Segla, K. N., Rabiou, H., Adjonou, K., Guibal, D., Bationo, A. B., Mahamane, A., Kokou, K., Langbour, P., Kokutse, A. D., Chaix, G. (2017): Useful near infrared spectroscopy model calibrations on solid wood samples of Pterocarpus erinaceus (Poir.) for physical, mechanical and colour properties. - Journal of Near Infrared Spectroscopy 25(4): 256-266.

[54] Sharma, N., Yadav, K., Cheema, J., Badda, N., Aggarwal, A. (2015): Arbuscular mycorrhizal symbiosis and water stress: a critical review. - Pertanika Journal of Tropical Agricultural Science 38(4): 427-453.

[55] Sinsin, A. B. (1993): Phytosociologie, Écologie, Valeur Pastorale, Production et Capacité de Charge des Pâturages Naturels Du Périmètre Nikki-Kalalé Au Nord-Bénin. - Université libre de Bruxelles.

[56] Sinsin, B., Matig, O. E., Assogbadjo, A. E., Gaoué, O. G., \& Sinadouwirou, T. (2004). Dendrometric characteristics as indicators of pressure of Afzelia africana Sm. dynamic changes in trees found in different climatic zones of Benin. Biodiversity \& Conservation, 13(8), 1555-1570.

[57] Smith, S., Read, D. (2008): Mycorrhizal symbiosis. - 3rd. ed. Academic Press. New York

[58] Talavera, M., Itou, K., Mizukubo, T. (2001): Reduction of nematode damage by root colonization with arbuscular mycorrhiza (Glomus spp.) in tomato-Meloidogyne incognita (Tylenchida: Meloidogynidae) and carrot-Pratylenchus penetrans (Tylenchida: Pratylenchidae) pathosystems. - Applied Entomology and Zoology 36(3): 387-392.

[59] Tamilarasi, S., Nanthakumar, K., Karthikeyan, K., Lakshmanaperumalsamy, P. (2008): Diversity of root associated microorganisms of selected medicinal plants and influence of rhizomicroorganisms on the antimicrobial property of Coriandrum sativum. - Journal of Environmental Biology 29(1): 127-134.

[60] Thoen, D., Ba, A. M. (1989): Ectomycorrhizas and putative ecto-mycorrhizal fungi of Afzelia africana Sm. and Uapaca guineensis Müll. Arg. in southern Senegal. - New Phytologist 113(4): 549-559.

[61] Tibiri, A., Banzouzi, J. T., Traore, A., Nacoulma, G. O., Guissou, I. P., Mbatchi, B. (2007): Toxicological assessment of methanolic stem bark and leaf extracts of Entada africana Guill. and Perr., Mimosaceae. - International Journal of Pharmacology 3(5): 393-399.

[62] Tibiri, A., Sawadogo, R. W., Ouedraogo, N., Banzouzi, J. T., Guissou, I. P., Nacoulma, G. O. (2010): Evaluation of antioxidant activity, total phenolic and flavonoid contents of Entada africana Guill. et Perr. (Mimosaceae) organ extracts. - Research Journal of Medical Sciences 4(2): 81-87.

[63] Traoré, B., Brancheriau, L., Perré, P., Stevanovic, T., Diouf, P. (2010): Acoustic quality of vène wood (Pterocarpus erinaceus Poir.) for xylophone instrument manufacture in Mali. - Annals of Forest Science 67: 815.

[64] Trouvelot, S., Van Tuinen, D., Hijri, M., Gianinazzi-Pearson, V. (1999): Visualization of ribosomal DNA loci in spore interphasic nuclei of glomalean fungi by fluorescence in situ hybridization. - Mycorrhiza 8(4): 203-206.

[65] Van Tuinen, D., Jacquot, E., Zhao, B., Gollotte, A., Gianinazzi-Pearson, V. (1998): Characterization of root colonization profiles by a microcosm community of arbuscular mycorrhizal fungi using 25S rDNA-targeted nested PCR. - Molecular Ecology 7(7): 879887.

[66] Verma, R. K., Thakur, A. K., Verma, P., Mishra, Y. (2016): Arbuscular mycorrhization and growth performance of Pterocarpus marsupium seedling raised from different seed sources of Chhattisgarh, India. - Indian Journal of Tropical Biodiversity 24(2): 151-157.

[67] Wang, B., Qiu, Y. L. (2006): Phylogenetic distribution and evolution of mycorrhizas in land plants. - Mycorrhiza 16(5): 299-363. 
[68] White, F. (1983): The vegetation map of Africa south of the Sahara. $-2^{\text {nd }}$ ed. UNESCO, Paris.

[69] Yorou, S. N., Agerer, R., Raidi, S. (2008): 'Afzeliaerhiza beninensis' + Afzelia africana Smith. - Description of Ectomycorrhizae 11(12): 1-8.

[70] Yuan, Z. L., Chen, Y. C., Ma, X. J. (2011): Symbiotic fungi in roots of Artemisia annua with special reference to endophytic colonizers. - Plant Biosystems 145(2): 495-502. 